\title{
An analysis of the possible impact of mandatory audit firm rotation on the transformation and market concentration of the South African audit industry
}

\begin{tabular}{|c|c|}
\hline \multicolumn{2}{|c|}{$\begin{array}{l}\text { Authors: } \\
\text { Michael Harber }{ }^{1} \\
\text { Ben Marx }^{2}\end{array}$} \\
\hline \multicolumn{2}{|c|}{$\begin{array}{l}\text { Affiliations: } \\
{ }^{1} \text { College of Accounting, } \\
\text { University of Cape Town, } \\
\text { Cape Town, South Africa }\end{array}$} \\
\hline \multicolumn{2}{|c|}{$\begin{array}{l}{ }^{2} \text { Department of Accountancy, } \\
\text { University of Johannesburg, } \\
\text { Johannesburg, South Africa }\end{array}$} \\
\hline \multicolumn{2}{|c|}{$\begin{array}{l}\text { Corresponding author: } \\
\text { Michael Harber, } \\
\text { michael.harber@uct.ac.za }\end{array}$} \\
\hline \multicolumn{2}{|c|}{$\begin{array}{l}\text { Dates: } \\
\text { Received: } 07 \text { June } 2018 \\
\text { Accepted: } 26 \text { Nov. } 2018 \\
\text { Published: } 25 \text { Apr. } 2019\end{array}$} \\
\hline \multicolumn{2}{|c|}{$\begin{array}{l}\text { How to cite this article: } \\
\text { Harber, M. \& Marx, B., 2019, } \\
\text { 'An analysis of the possible } \\
\text { impact of mandatory audit } \\
\text { firm rotation on the } \\
\text { transformation and market } \\
\text { concentration of the South } \\
\text { African audit industry', } \\
\text { Journal of Economic and } \\
\text { Financial Sciences } 12(1) \text {, } \\
\text { a227. https://doi.org/ } \\
\text { 10.4102/jef.v12i1.227 }\end{array}$} \\
\hline \multicolumn{2}{|c|}{$\begin{array}{l}\text { Copyright: } \\
\text { (C) 2019. The Authors } \\
\text { Licensee: AOSIS. This } \\
\text { is licensed under the } \\
\text { Creative Commons } \\
\text { Attribution License. }\end{array}$} \\
\hline \multicolumn{2}{|l|}{ Read online: } \\
\hline 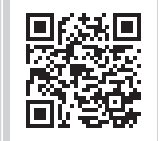 & $\begin{array}{l}\text { Scan this QR } \\
\text { code with your } \\
\text { smart phone or } \\
\text { mobile device } \\
\text { to read online. }\end{array}$ \\
\hline
\end{tabular}

Orientation: Consistent with global concerns regarding the quality of audits and regulatory changes in Europe, South African audit regulations will require audit firms to rotate clients periodically, in an attempt to safeguard auditor independence and audit quality. In 2017 the South African audit regulator issued a ruling requiring mandatory audit firm rotation (MAFR) every 10 years, effective April 2023, primarily intended to improve audit quality. In addition to audit quality improvement, the regulator also believes that MAFR will stimulate transformation in the audit profession by building capacity of black-owned audit firms and allowing opportunities for small- and medium-tier audit firms to compete for the audits of listed companies.

Research purpose: This study explores the perceptions of auditors and audit committee chairs of Johannesburg Stock Exchange-listed companies with regard to the direct and indirect financial effects of the implementation of MAFR in South Africa with respect to black economic empowerment and market concentration.

Motivation for the study: No studies have explored this controversial additional objective of MAFR in South Africa.

Research approach, design and method: An exploratory mixed-methods design is employed, using questionnaires derived from a review of the academic research and professional debate concerning MAFR.

Main findings: Contrary to the intentions of the regulator, MAFR may not result in improved transformation of the audit profession and could in fact reduce the capacity of audit firms to pursue transformation initiatives. In addition, MAFR may not decrease the current degree of audit domination of the Big 4 firms of the JSE, possibly even further concentrating the industry, as audit committees and shareholders may be reluctant to appoint mid-tier firms as auditors of the large listed companies.

Practical/managerial implications: Industry stakeholders and the regulator should consider targeted interventions to mitigate the potential for impaired transformation and further concentration of the industry which may result from implementation of MAFR in 2023.

Contribution/value-add: The findings and conclusions will contribute to addressing concerns regarding the rate of black participation in the industry, as well as mitigating the potential unintended consequences of MAFR.

Keywords: mandatory audit firm rotation; market concentration; audit profession; transformation; audit quality; audit regulation.

\section{Introduction}

Mandatory audit firm rotation (MAFR) has received a great deal of attention from national audit regulators and researchers in recent years. Proponents of MAFR argue that long-tenure relationships between audit firms and clients can lead to audit failures because of high levels of familiarity that impair auditors' independence and professional scepticism. Opponents argue that long-tenure auditor-client relationships lead to valuable client- and industry-specific knowledge over time, resulting in enhanced audit quality (Aschauer \& Quick 2018; Fontaine, Khemakhem \& Herda 2016).

In June 2017 the Independent Regulatory Board for Auditors (IRBA), the South African statutory body responsible for regulating the auditing profession, issued a regulation requiring MAFR for 
all 'public-interest entities', effective 2023, on a 10-year rotation basis (IRBA 2017a), which includes companies listed on the Johannesburg Stock Exchange (JSE). The IRBA's move from audit partner rotation on a 5-year rotation basis towards firm rotation follows similar MAFR regulations implemented in Europe in 2014 (European Commission 2014). The US regulator has repeatedly considered MAFR over the past two decades but has consistently decided in favour of audit partner rotation because of the negative consequences inherent in MAFR (Fontaine et al. 2016). These two large auditing jurisdictions illustrate the international divide on the issue. Whereas some countries have adopted MAFR in recent years, most $\mathrm{t}^{1}$ have decided against it or implemented it and then subsequently repealed it, usually in favour of audit partner rotation (Ewelt-Knauer, Gold \& Pott 2013).

The audit committee (AC) has the legislative role of mitigating the risk of impaired auditor independence. In terms of Section 94 of the Companies Act, 2008 (Act No. 71 of 2008), an $\mathrm{AC}$ of a public interest entity is required to formally assess the independence of the external auditor from management as well as approve the nature and extent of any non-audit services provided, before recommending the auditor to shareholders for appointment (RSA 2008). An important function of the $\mathrm{AC}$ is also to maintain and improve the quality of the company's financial reporting (Ghafran \& O'Sullivan 2013; Knechel et al. 2013). Some opponents of MAFR have claimed that forcing audit firm rotation will restrict the role of the AC. As argued by Shango (2017), the CEO of PwC Southern Africa:

The audit committee fulfils an important role in a properly functioning capital market like South Africa in overseeing the external audit process and making the auditor appointment decision. MAFR undermines this responsibility and takes away the audit committee's freedom to decide which accounting firm best meets the needs of the company and its shareholders. It conflicts with their statutory responsibilities under the Companies Act. As such MAFR reduces the audit committee's ability to fully discharge its oversight responsibilities and in turn disenfranchises shareholders' ability to obtain the highest quality audit in the most efficient way. (p. 4)

The MAFR ruling in South Africa followed a period of stakeholder consultation and public debate, in which it was clear that there was significant pushback from audit partners and members of the wider business community (Harber \& West 2017; Ramon 2016). The primary reason for implementing MAFR is the concern of the IRBA that the quality of audits performed by audit firms on South African listed companies is deteriorating. This is evidenced by recent high-profile corporate financial scandals and the poor results of regulatory inspections of audit work. The regulator

1.According to PwC Inc. of the top 20 countries ranked by the World Economic Forum in terms of financial market development (World Economic Forum 2017), six EU countries have adopted MAFR by virtue of being in the EU (Finland, Norway, countries have adopted MAFR by virtue of being in the EU (Finland, Norway, Sweden, Luxembourg, the UK and Germany) and only one other country, namely China, currently applies MAFR (Shango 2017). The remaining 13 countries have either not adopted MAFR or have implemented and since repealed it. More detailed information concerning country adoption of audit rotation regulations can be found in research by Casterella and Johnston (2013); Cameran et al. (2015); Hakwoon, Hyoik and Jong Eun (2015); Fontaine, Khemakhem and Herda (2016); and Harbe and West (2017). believes that excessively long audit tenures have resulted in significant threats to auditor independence and professional scepticism, such that the ability of the auditor to independently question the financial reporting and conduct of management has been compromised (IRBA 2016b, 2017b).

Unlike other international jurisdictions, the IRBA has clearly articulated its intention to pursue MAFR for two additional objectives. Apart from the primary goal, which is to improve auditor independence, the IRBA intends to promote a more competitive environment, which is to positively influence audit quality and to promote black economic participation in the audit profession by creating more opportunities for small and mid-tier audit firms to enter certain markets, provided they are competent to audit in those markets (IRBA 2015, 2016a, 2016b). These have been referred to as market concentration and transformation objectives. In this context, 'black' refers to the race categories provided in Section 1 of the Broad-Based Black Economic Empowerment Amendment Act, 2013, which refers to 'African black', 'coloured' and 'Indian/Asian'.

The purpose of this study is to examine the perceptions of auditors and ACs with respect to whether or not MAFR will increase the rate of transformation in the audit industry and reduce market concentration, as intended by the IRBA. The study contributes to the controversial and ongoing debate in South Africa regarding the need for, and efficacy of, MAFR as well as the priority of transforming the audit profession.

\section{Literature review}

Proponents of MAFR argue that long-tenure relationships between audit firms and clients can lead to reduced audit quality as the auditors' independence and professional scepticism become impaired (IRBA 2016b). Opponents, on the other hand, argue that long-tenure auditor-client relationships increase audit quality as the auditor acquires client- and industry-specific knowledge over time (Aschauer \& Quick 2018; Fontaine et al. 2016). As such, the concept of audit quality is at the centre of the debate. DeAngelo (1981:186) provides a helpful definition of the concept of audit quality, even though it may not be all-encompassing. Audit quality can be considered as the market assessed joint probability that a given auditor will both discover a breach in a client's accounting system and report the breach'. This definition has been employed by many studies ${ }^{2}$ on audit quality since 1981 and highlights the role of the auditor in uncovering and reporting financial misconduct by management, either in terms of accepted accounting reporting standards or in terms of financial regulations applicable to the organisation.

The research on the effectiveness of MAFR in improving audit quality is mixed. Stefaniak, Robertson and Houston (2009) reviewed the literature and concluded that the majority

2.This is a useful definition that has been adopted by numerous recent studies on the topic such as those of Ball, Tyler and Wells (2015), Fontaine et al (2016), Hakwoon Hyoik and Jong Eun (2015), Jackson, Moldrich and Roebuck (2008), Kwon, Lim and Simnett (2014), Lennox, Wu and Zhang (2014), Lu and Sivaramakrishnan (2009) and Simnett (2014), Lennox, Wu and Zhang (2014), Lu and Sivaramakrishnan (2009) and
Tepalagul and Lin (2015). The definition is important because it identifies the purpose of auditing. 
of research on MAFR provides little evidence that it is effective in improving audit quality. Casterella and Johnston (2013), on the other hand, reviewed 24 academic studies on MAFR and argued that results from studies involving mandatory (as opposed to voluntary) auditor switching offer some support for MAFR. However, this study does not delve any further into this particular aspect of the MAFR debate as its sole purpose is to explore the two additional IRBA objectives for MAFR in South Africa, namely to lower market concentration and improve transformation in the audit profession.

\section{The role of the audit committee in auditor appointment}

As previously described, the AC is responsible for assessing auditor independence and the suitability of the auditor, both the audit firm and the engagement partner, before providing shareholders with their recommendation. The AC therefore plays a key role in the governance of the company insofar as it is responsible for the appointment, compensation and oversight of external auditors (Marx 2009). This process of oversight and review includes an assessment of the nature and extent of any non-audit services provided, to ensure threats to independence are properly monitored (RSA 2008).

Interview studies involving external auditors (Cohen, Krishnamoorthy \& Wright 2010; Harber 2016) and AC members (Beasley et al. 2009; Fontaine et al. 2016) all emphasise that the importance of the $\mathrm{AC}^{\mathrm{C}} \mathrm{s}$ role in monitoring auditors and financial reporting quality has increased globally in recent years. A common criticism of the IRBA's decision to implement MAFR in South Africa is that it neglects the important role that a company's AC plays in maintaining the independence of the auditor from company management influence (Harber 2016; Harber \& West 2017), seeking instead to regulate audit firm rotation rather than allow the AC to decide on the appropriate time to appoint new auditors.

Cohen et al. (2010) provide evidence that ACs have become considerably more active and diligent in the post-SarbanesOxley Act era; however, their independence from management is still a concern in practice. Audit committees are again seen as having sufficient expertise and power to fulfil their responsibilities, with members playing important roles in overseeing internal controls, focusing on reporting quality, identifying risks, asking challenging questions and overseeing the whistle-blowing process (Cohen et al. 2010). Audit committees are increasingly taking responsibility for the quality of corporate financial reporting, and research confirms that increased independence and expertise of $\mathrm{AC}$ is resulting in improved financial reporting quality (Ghafran \& O’Sullivan 2013).

In order for the AC to be effective in this governance role, it needs to be independent of management. Ghafran and O'Sullivan (2013), performing a review of AC literature, found evidence that larger and more independent ACs as well as those with financial expertise, were more likely to seek a higher level of external audit coverage and assurance. In addition, there is evidence that more independent ACs are associated with the purchase of lower levels of nonaudit services from auditors, thereby seeking to preserve the independence of the external audit process. These findings in an international context are consistent with those of Marx (2009a) in South Africa and emphasise the importance of considering the role of the AC in safeguarding the independence of the external auditor and the MAFR debate.

\section{Market concentration in the audit profession}

Market concentration refers to the degree to which smaller companies account for the total market. A highly concentrated market therefore means that a few companies comprise the majority of the market share or sales volume. Market concentration may be considered one measure of the degree of competition or rivalry between companies in a market (Velte \& Stiglbauer 2012).

A high degree of audit firm concentration is not unique to South Africa. Internationally, regulators have raised concerns over the concentration of supply in the hands of the Big $4^{3}$ accounting firms and the potentially adverse effects of this concentration on audit markets and the quality of audits in these legal jurisdictions (Francis, Michas \& Seavey 2013). Velte and Stiglbauer (2012:156) believe that audit market concentration 'is a permanent, worldwide phenomenon' and is caused 'by economies of scale, growing needs of the clients regarding business establishments across national boundaries of the audit firms and prior mergers of audit companies'. Over the past 25 years, the audit market has undergone a progressive concentration, moving from the 'Big 8' to the 'Big 5' to the current 'Big 4', as can be seen in Figure 1.

Most audit engagements and almost all audit fees from publicly traded companies in the USA involve just the Big 4 audit firms. In the USA in 2010, the Big 4 had $67 \%$ of audit engagements and collected over $94 \%$ of audit fees (Gerokos \& Syverson 2015). Velte and Stiglbauer (2012) found that audit markets in many other developed economies show similar concentration among the Big 4. According to the Financial Times, 'only two FTSE 100 companies are not audited by the Big Four. ... At the end of 2014, the Big Four audited $95 \%$ of the world's 500 largest companies' (Agnew 2016:1).

These dominant audit firms have been characterised as high quality, differentiated suppliers that command higher audit fees (Chu et al. 2015). This industry consolidation could therefore be considered a normal economic response to the increased pressure for better quality services in an attempt to

3.The 'Big 4' refers to Deloitte Inc., EY Inc., KPMG Inc. and PWC Inc., the four largest international audit firm networks. 


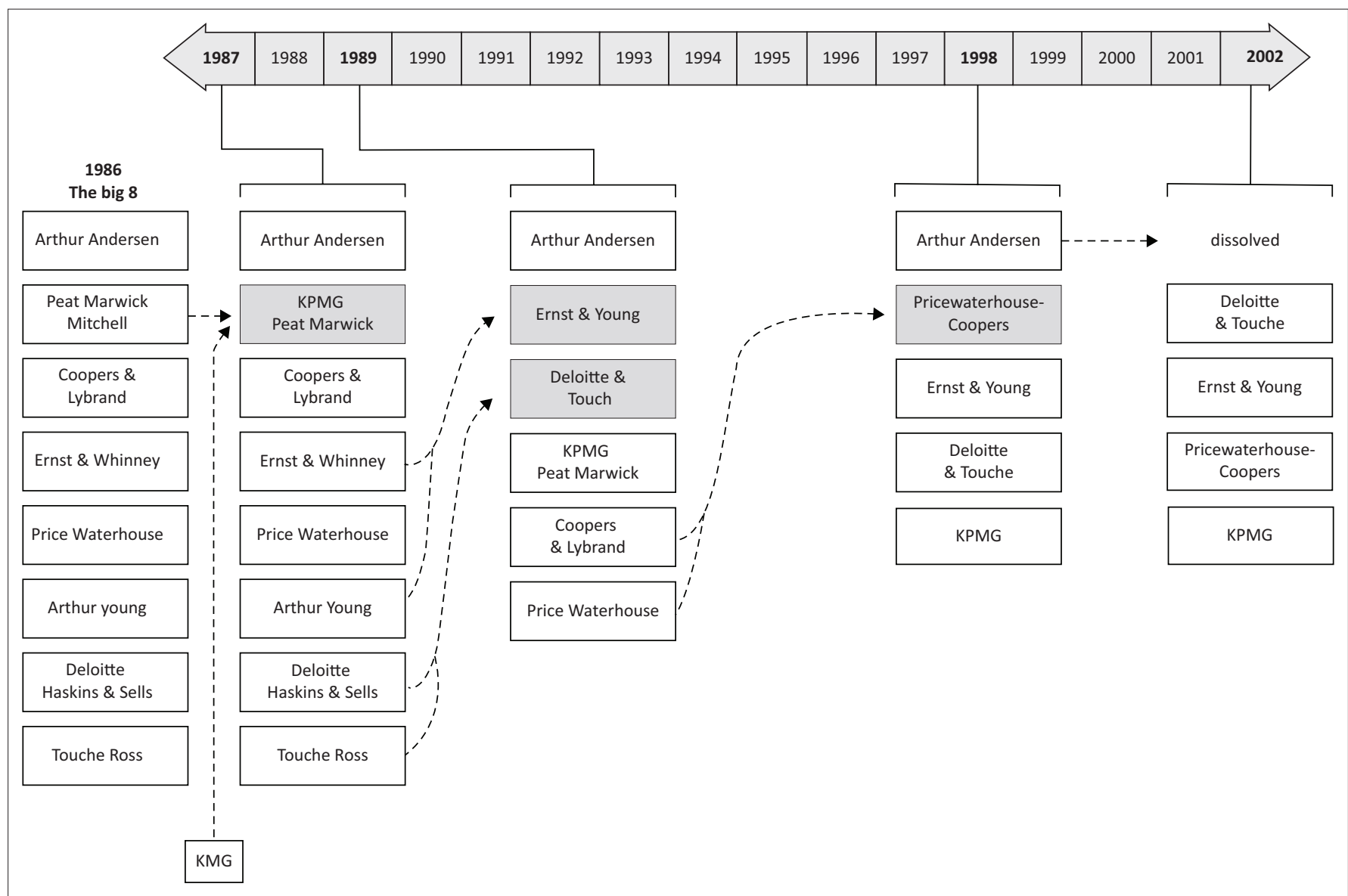

Source: Velte, P. \& Stiglbauer, M., 2012, 'Audit market concentration in Europe and its influence on audit quality', International Business Research 5(11), 146-161. https://doi.org/10.5539/ibr. v5n11p146

FIGURE 1: 1980s and 1990s: Significant mergers in the audit market.

optimise scaling and industry specialisation. However, Velte and Stiglbauer (2012) contend that this concentration of suppliers in the audit market is often assessed negatively from a competition policy perspective for the following reasons:

- The incentives to ensure cost-efficiency and appropriate audit quality are decreasing.

- Higher barriers of entry for small- and medium-sized audit firms exist.

- A strong influence of the Big 4 on the development of international accounting and audit standards (International Financial Reporting Standards [IFRSs] and International Standards on Auditing [ISAs]) must be assumed.

Furthermore, Velte and Stiglbauer (2012) posit that this lack of competition may result in oligopolistic pricing, a decline in the quality of audits and other services provided by audit firms as well as a decrease in the stability of capital markets and investor confidence. This may in turn result in corporate failures, affecting the broader economy. These risks are acknowledged by other researchers (Chu et al. 2015; Francis et al. 2013).

Velte and Stiglbauer (2012) conclude that MAFR may have the unintended effect of significantly increasing audit firm transaction costs and price dumping strategies ('low balling'), which will in turn compromise audit quality. Velte and Stiglbauer (2012) also question the ability of mediumsized firms (with limited capacities) to audit large, multinational companies. The question arises as to whether smaller firms have the resources, including staff and experience, to service large, complex groups of companies. If not, then this will negatively affect audit quality. These same concerns were expressed by the South African audit partners interviewed by Harber (2016), who believed that MAFR would in fact increase concentration as ACs and shareholders of large companies would be reluctant to appoint mid-tier firms. This is consistent with the findings of Chen and Zhou (2007) in a Chinese context, which indicate that upon rotation of an audit firm under a system of MAFR, ACs would simply replace one Big 4 firm with another Big 4 firm.

The IRBA has specific concerns regarding the perceived dominance of the Big 4 audit firms in South Africa over JSE listed company audits. The problem has been expressed as twofold. Firstly, a high concentration of the Big 4 firms increases the risk that the loss of one auditing firm will dusrupt the economy. An audit failure could 'possibly disrupt stability in the financial market and damage investor confidence' (IRBA, 2016b:12). Secondly, the high concentration 


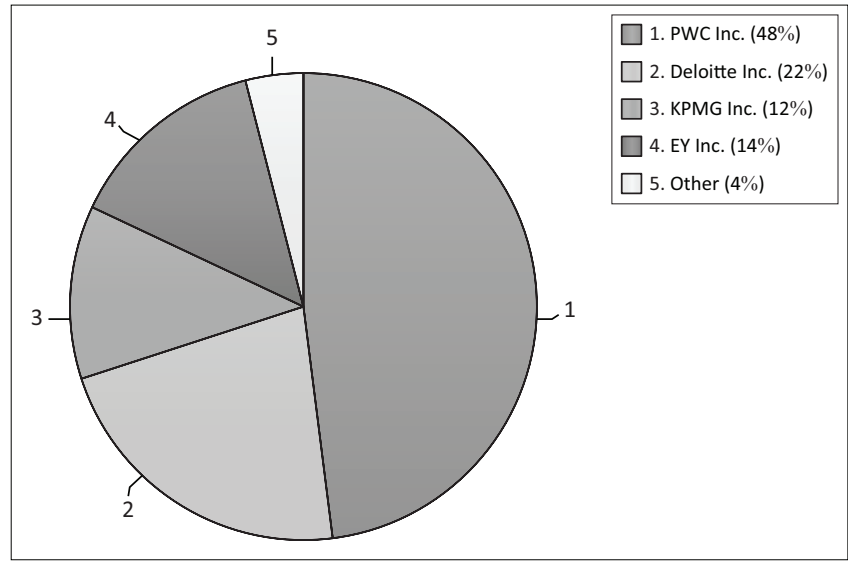

Source: Adapted from data provided by the Independent Regulatory Board for Auditors (IRBA), 2016b, The IRBA consultation paper, p.12, The Independent Regulatory Board for Auditors, viewed 15 November 2016, from https://www.irba.co.za/news-headlines/pressreleases

FIGURE 2: Market concentration of listed companies in South Africa measured by market capitalisation.

is limiting opportunities for other audit firms to tender and compete for the audits of listed companies and public-interest entities. Figure 2 illustrates the degree of market concentration by the Big 4 servicing JSE listed companies. The figure shows that only $4 \%$ of companies (by market capitalisation) are audited by non-Big 4 firms.

\section{Transformation of the South African audit profession}

Much of the public debate regarding MAFR, including public hearings before the South African parliament's Standing Committee on Finance in 2017, has focused on the aspects of transformation, black economic empowerment and market concentration (Peyper 2017). The 2016 IRBA consultation paper on MAFR, while stating that improving auditor independence and hence audit quality was the main objective of MAFR, indicated that transformation and market concentration were also intended benefits of MAFR legislation:

The IRBA considers MAFR as an important measure to increase competition and thereby improve audit quality ... MAFR is not intended to address transformation but rather to strengthen auditor independence. However, the slow pace of transformation as highlighted in our demographic and professional landscape study, certainly raised some serious concerns. The IRBA supports the fact that creating the opportunity for access to work as companies become due for rotation, will help more firms participate in a more meaningful way. It concedes that the MAFR rule on its own will not achieve all the transformation objectives required in the South African context; however, it can contribute to building capacity. (IRBA 2016e:29)

In a South African context, the IRBA Board has also recognised the challenges with lack of economic transformation and domination by certain firms within the profession. Out of the 353 audit partners who sign off on the financial statements of all JSE listed companies, only nine are Black African and over $90 \%$ are audited by a few firms. We will only see true empowerment when opportunities are provided equally amongst everyone. (IRBA 2016b)
These objectives of the IRBA regarding MAFR as a mechanism to accelerate transformation of the audit profession were further emphasised in 2017 by the CEO of the IRBA, Bernard Augulas, who stated that:

... the harsh reality is that of the 4,283 registered auditors in South Africa, $74.8 \%$ are white and only $10.5 \%$ are black Africans. We believe that, while some initiatives have been implemented, more must be done. It is not just about increasing the number of black trainee accountants; it is about giving black accountants and auditors long-term prospects in the profession - prospects that are equivalent to those of their counterparts. This requires a cultural shift and a more inclusive approach that will provide black accountants with a positive experience at the firms, resulting in higher retention. Transformation is not about the de-racialisation of the overall profession; it is about financial inclusion, ownership and access to markets and opportunities. (IRBA 2017:2-3)

Black economic empowerment, also referred to as transformation or affirmative action, is widely recognised as an important imperative in the South African economy, acknowledged by both business and government as an ethical and urgent national priority (Marais 2010; Ponte, Roberts \& van Sittert 2007). South Africa's history of apartheid and its continuing impact on the economy and society today has resulted in a widespread desire to 'level the playing field' and redress the inequalities of the past by giving historically disadvantaged South African citizens economic privileges previously not available to them (Marais 2010; Ponte et al. 2007). Black economic empowerment has been described by the South African government as follows:

\footnotetext{
... an integrated and coherent socio-economic process ... aimed at redressing the imbalances of the past by seeking to substantially and equitably transfer and confer the ownership, management and control of South Africa's financial and economic resources to the majority of its citizens. It seeks to ensure broader and meaningful participation in the economy by black people to achieve sustainable development and prosperity. (BEE Commission 2001:2)
}

Accordingly, it is evident that the IRBA is considering MAFR as a mechanism to address the racial transformation of the audit industry, notably the inability of smaller audit firms to compete for listed company audits currently monopolised by the Big 4 audit firms.

However, audit partners, regardless of firm size, do not generally believe that MAFR will improve transformation in the South African audit market. Instead, they consider that the rotation of audit firms for listed companies will most likely only result in another Big 4 firm being appointed, as opposed to a smaller audit firm. Audit partners also expressed the opinion that MAFR would significantly increase costs incurred by audit firms, to such a degree that it would force firms to reduce spending on bursary programmes and other transformation initiatives (Harber 2016). This view is further supported by the letters of response to the IRBA consultation paper by the Big 4 firms' leadership, in which they expressed 
commitment towards improved transformation but concern that MAFR was an inappropriate means of achieving this. They also provided the IRBA with statistics that showed the progress they had made in transformation objectives over recent years, indicating that MAFR should not be used as a tool to transform the audit industry. Instead, this would be better achieved if left to the firms' own existing regulations, as is being done in other industries (Bam 2017; Bourne 2017; Oddy 2017; Shango 2017).

Concerns raised by the firms over the negative impact of MAFR included the ability to attract, retain and grow the pool of audit resources and skills in the country and the repercussions of this on audit quality in the years ahead. The retention of skilled black professionals is another challenge that is preventing the firms from meeting transformation targets, as black professionals often leave the profession to pursue better-paying jobs in commerce and industry. This is believed to have a further negative impact on the ability of the profession to attract and retain the best talent and is likely to undermine audit quality and the ability to transform the profession (Shango 2017). According to the South African Institute of Chartered Accountants (SAICA), in 2002 the membership base of qualified professional accountants comprised only 322 African and 222 Coloured chartered accountants, while the remaining $92.3 \%$ were white chartered accountants. In 2017, these numbers had grown to 5107 and 1577, respectively, with $72.3 \%$ being white. Of the 12288 newly qualifying chartered accountants between 2012 and 2017, 49\% have been African black, Coloured or Indian a significant improvement in transformation of the accounting profession (SAICA 2017). However, despite this increase in transformation by SAICA, the auditing profession is evidently struggling to retain black professionals.

Regarding the potential of MAFR to increase costs, the large audit firms explained that these costs will have a negative impact on the ability of firms to invest in methodologies, transformation and attracting talent. According to Bam (2017), the firms have a very limited ability to absorb these costs and it would require spending in areas such as training and bursaries to be redirected to tendering for work, given the pressure on financial results.

Considering these additional objectives of improving transformation and reducing market concentration, the results of the empirical study will significantly contribute to the existing body of knowledge on the consequences of MAFR on the South African auditing environment. The study will also be useful in determining whether MAFR has the potential to increase the rate of transformation in the audit industry and reduce market concentration, as intended by the IRBA.

\section{Research methodology}

The parties most directly involved in the audit process, including auditor appointment, within a listed company are the $\mathrm{AC}$ and the auditors themselves. The audit partners, as the most senior staff and owners of the firm, are ultimately responsible for transformation initiatives in the firm, and it is reasonable to expect that ACs will consider audit firm transformation statistics in the decision of which firm to recommend for appointment.

The AC has the responsibility, in terms of South African corporate governance principles and legislation, to recommend the auditor to shareholders for appointment at the company's annual general meeting, following oversight of the external audit process and auditor independence. Therefore, the role of the $\mathrm{AC}$, as led by the chair of the $\mathrm{AC}$ (AC chair), is necessary for the proper functioning of the audit process and the quality of the audit outcome (Marx 2009). This study is intended to explore the perceptions of experienced AC chairs of JSE listed companies to whom the IRBA MAFR ruling applies. As the MAFR ruling of the IRBA applies primarily to JSE listed company audit firms, the target population of the empirical study was directed at the audit partners accredited with the JSE, as well as the AC chairs of the top 100 JSE listed companies.

The questionnaires were distributed to the group-level AC chairs of the top 100 companies listed on the JSE according to market capitalisation, excluding companies with a secondary listing on the JSE. The proportion of listed companies with a primary listing on the JSE that were sent the questionnaires represents approximately $92 \%$ of the JSE market capitalisation (excluding secondary listings). As such, this proportion represents a broad spectrum of stakeholder interests in South African capital markets. As per the review of the latest company records and annual reports for each of the companies, it was determined that seven individuals act as AC chairs on more than one company in the target group of 100. Considering that these individuals would only complete the survey once (as the tool is not company-specific), the total population was reduced to 93 AC chairs.

Distribution was done by the JSE via formal email to 305 registered auditors and 93 AC chairs in August 2017, requesting participation in the study. Data collection ended, with the survey tool being closed, on 31 October 2017. The researchers sent follow-up correspondence to recipients during this period to encourage participation. The survey tool was electronic, accessed via a URL link in the email to each recipient. The response rates achieved are displayed in Figure 3.

In comparison to similar, survey-based auditing research, Daugherty et al. (2012) received a response rate of $46 \%$, Bamber and Iyer (2007) received a response rate of $23 \%$ and Brazel, Carpenter and Jenkins (2010) received a response rate of $48.8 \%$. Therefore, the response rates received in this study across both participant groups are deemed comparable and acceptable. 


\begin{tabular}{|l|c|c|c|}
\hline Variable & Recipients & $\begin{array}{c}\text { Complete and useable } \\
\text { responses }\end{array}$ & Response rate (\%) \\
\hline Audit partners & 305 & $112^{*}$ & 36.7 \\
\hline $\begin{array}{l}\text { Audit committee } \\
\text { chairs }\end{array}$ & 93 & 41 & 44.1 \\
\hline
\end{tabular}

Note: *, 66 respondents (58.9\%) were from Big 4 firms and 46 from non-Big 4 firms $(41.1 \%)$. FIGURE 3: Survey response rates.

\section{Ethical considerations}

Ethical approval for the research was obtained from the Faculty of Economic and Financial Sciences (FEFS), FEFS Research Ethics Committee, at the University of Johannesburg. The associated ethical clearance number is FEFSREC2017081401.

\section{Analysis of findings}

Participants were mostly required to provide the extent of their agreement to statements on a five-point Likert scale (1 - strongly agree, 3 - neutral, 5 - strongly disagree), similar to auditing studies performed by Aschauer and Quick (2018), Bergner (2011), Daugherty et al. (2012) and Trivellas et al. (2015). $P$-values, using a two-tailed $t$-test, were calculated by comparing means to the scale midpoint, which is a meaningful midpoint separating general agreement from disagreement with the survey statement. Written comments (qualitative data) were collected by means of comment boxes provided in the survey.

\section{Auditors' views on the rate of transformation of the auditing profession}

Table 1 shows that auditors agree that the rate of transformation, especially in the context of the senior role of audit partners, is unacceptable (mean $=3.53$; $p<0.001$ ). Big 4 partners expressed this sentiment with slightly more conviction than did the non-Big 4 partners, with means of 3.62 and 3.40, respectively. Audit committee chairs share a similar sentiment, although the results are closer to the neutral (mean $=3.34 ; p<0.05$ ). From these results, it is fair to conclude that these two groups believe that further efforts and interventions are necessary to speed up the rate of black economic participation in the audit industry.

Considering that the IRBA believes MAFR will promote transformation by creating more opportunities for small and mid-tier audit firms to enter certain markets, it is clear that transformation and market concentration are linked objectives. Black economic participation in the audits of JSE listed companies, according to the IRBA's reasoning, will come via increased participation of the non-Big 4 firms, especially the majority 'black-owned' audit firms such as SizweNtsalubaGobodo Inc. However, in 2018 SizweNtsalubaGobodo Inc. merged with Grant Thornton to become SizweNtsalubaGobodo Grant Thornton (Grant Thornton South Africa 2018). Another significant blackowned audit firm, Nkonki Inc., placed itself into liquidation in 2018, following allegations of improper conduct and the
TABLE 1: Perspectives on transformation statistics. Statement: According to the Independent Regulatory Board for Auditors (IRBA), of the 4283 registered auditors in South Africa, $74.8 \%$ are white and only $10.5 \%$ are black Africans. Of the 353 audit partners signing off on listed company audits, only 9 are black African. Based on this, please provide your response to the following statement: The rate of transformation in the audit profession is acceptable.

\begin{tabular}{|c|c|c|c|c|c|}
\hline No. & Responses & Endpoints, Midpoint & Mean & $\begin{array}{l}\text { Standard } \\
\text { deviation }\end{array}$ & $\begin{array}{c}\text { Diff from } \\
\text { neutral }\end{array}$ \\
\hline 1. & $\begin{array}{l}\text { Audit partners' } \\
\text { response }\end{array}$ & $\begin{array}{l}1=\text { Strongly agree } \\
3=\text { Neutral } \\
5=\text { Strongly disagree }\end{array}$ & 3.53 & 1.06 & $0.53 * *$ \\
\hline 2. & $\begin{array}{l}\text { Audit committee } \\
\text { chairs' response }\end{array}$ & $\begin{array}{l}1=\text { Strongly agree } \\
3=\text { Neutral } \\
5=\text { Strongly disagree }\end{array}$ & 3.34 & 1.00 & $0.34 *$ \\
\hline
\end{tabular}

Note: ${ }^{*}, *$ Denote significance at $<$ or $=0.05$ and 0.001 levels, respectively (two-tailed).

loss of a key client - the Auditor General of South Africa (Niselow 2018). This raises the question of whether MAFR will improve transformation, considering that most nonBig 4 firms are not black-owned but rather international firm networks such as BDO, Grant Thornton, PKF, Mazars, RSM, Baker Tilly, Moore Stephens and so on. If these nonBig 4 firms do receive more appointments over listed companies under a system of MAFR, this raises the question of whether this will indeed increase transformation, especially considering that the Big 4 firms consider themselves to be the most transformed in the industry (Shango 2017).

It is therefore appropriate to analyse the results of the audit partner surveys separating the Big 4 firm partners from the non-Big 4, as there could be differing incentives and perhaps bias with respect to the MAFR debate on the topic of transformation. Non-Big 4 firm partners, according to the IRBA's reasoning, stand to benefit from MAFR through securing appointments of JSE listed companies as these engagements are placed out to the market for tender. The results for each subgroup are therefore shown in Tables 2 and 3.

As can be expected, from Statement 2, the Big 4 partners (mean $=2.45 ; p<0.001)$ feel more strongly that MAFR will inhibit their current progression towards transformation targets. Overall, however, both groups do not share the IRBA's opinion that MAFR will be beneficial for the transformation of the audit profession. The results for Statement 5 challenge the IRBA's position that MAFR will be a positive contribution to the goal of growing black participation in the profession ( $p<0.001$ for both groups). Even the non-Big 4 firms, which the IRBA believes will stand to benefit from additional clients and therefore fee revenue and growth, do not feel that MAFR will achieve the result of a more transformed profession (Statement 5; mean $=3.79 ; p<0.001$ ). These results provide evidence in support of the opinions of the Big 4 partners in their responses to the IRBA consultation paper (Bam 2017; Bourne 2017; Oddy 2017; Shango 2017). The CEO of PwC South Africa, Dion Shango (2017), made the argument, which was a recurring theme in the comments of responding auditors, that the most transformed firms are, in fact, the Big 4 firms in terms of the number of black staff employed at all levels in the profession. This is consistent with 
TABLE 2: Big 4 audit partners' perspectives on transformation.

\begin{tabular}{|c|c|c|c|c|c|}
\hline No. & Statement & Endpoints, midpoint & Mean & SD & Diff from neutral \\
\hline 2. & $\begin{array}{l}\text { MAFR will reduce the ability of audit firms to pursue internal transformation objectives, } \\
\text { that is, hinder the ability of firms to achieve transformation targets. }\end{array}$ & $\begin{array}{l}1=\text { Strongly agree } \\
3=\text { Neutral } \\
5=\text { Strongly disagree }\end{array}$ & 2.45 & 1.23 & {$[0.55] * * *$} \\
\hline 3. & $\begin{array}{l}\text { MAFR will impose additional costs on the audit firms, resulting in a negative financial } \\
\text { impact on the ability of firms to invest in transformation and attract talent. }\end{array}$ & $\begin{array}{l}1=\text { Strongly agree } \\
3=\text { Neutral } \\
5=\text { Strongly disagree }\end{array}$ & 1.94 & 0.92 & {$[1.06] * * *$} \\
\hline 4. & $\begin{array}{l}\text { The additional costs MAFR will impose on the audit firms will require a redirection of } \\
\text { spending away from areas such as training and bursaries and into tendering for work. }\end{array}$ & $\begin{array}{l}1=\text { Strongly agree } \\
3=\text { Neutral } \\
5=\text { Strongly disagree }\end{array}$ & 2.48 & 1.09 & {$[0.52] * * *$} \\
\hline 5. & MAFR will improve the transformation statistics in the South African audit profession. & $\begin{array}{l}1=\text { Strongly agree } \\
3=\text { Neutral } \\
5=\text { Strongly disagree }\end{array}$ & 4.21 & 0.75 & $1.21 * * *$ \\
\hline 6. & $\begin{array}{l}\text { Transformation of the audit profession will best be progressed via MAFR, rather than } \\
\text { through existing and/or improved efforts within the audit firms themselves. }\end{array}$ & $\begin{array}{l}1=\text { Strongly agree } \\
3=\text { Neutral } \\
5=\text { Strongly disagree }\end{array}$ & 4.73 & 0.54 & $1.73^{* * *}$ \\
\hline 7. & $\begin{array}{l}\text { The lack of black registered auditors in South Africa is primarily indicative of the } \\
\text { disproportionately small pool of black Chartered Accountants and the disproportionate } \\
\text { racial demographic of qualifying chartered accountants. }\end{array}$ & $\begin{array}{l}1=\text { Strongly agree } \\
3=\text { Neutral } \\
5=\text { Strongly disagree }\end{array}$ & 2.47 & 1.26 & {$[0.53] * *$} \\
\hline
\end{tabular}

Note: $* *$ and $* * *$, denote significance at $p<$ or $=0.01$ and 0.001 levels, respectively (two-tailed). Numbers shown in brackets represent negative numbers.

MAFR, mandatory audit firm rotation; SD, standard deviation.

TABLE 3: Non-Big 4 audit partners' perspectives on transformation.

\begin{tabular}{|c|c|c|c|c|c|}
\hline No. & Statement & Endpoints, midpoint & Mean & SD & Diff from neutral \\
\hline 2. & $\begin{array}{l}\text { MAFR will reduce the ability of audit firms to pursue internal transformation } \\
\text { objectives, that is, hinder the ability of firms to achieve transformation targets. }\end{array}$ & $\begin{array}{l}1=\text { Strongly agree } \\
3=\text { Neutral } \\
5=\text { Strongly disagree }\end{array}$ & 2.53 & 1.16 & {$[0.47]^{* *}$} \\
\hline 3. & $\begin{array}{l}\text { MAFR will impose additional costs on the audit firms, resulting in a negative financial } \\
\text { impact on the ability of firms to invest in transformation and attract talent. }\end{array}$ & $\begin{array}{l}1=\text { Strongly agree } \\
3=\text { Neutral } \\
5=\text { Strongly disagree }\end{array}$ & 2.19 & 1.16 & {$[0.81]^{* * *}$} \\
\hline 4. & $\begin{array}{l}\text { The additional costs MAFR will impose on the audit firms will require a redirection of } \\
\text { spending away from areas such as training and bursaries and into tendering for work. }\end{array}$ & $\begin{array}{l}1=\text { Strongly agree } \\
3=\text { Neutral } \\
5=\text { Strongly disagree }\end{array}$ & 2.45 & 1.14 & {$[0.55]^{* *}$} \\
\hline 5. & MAFR will improve the transformation statistics in the South African audit profession. & $\begin{array}{l}1=\text { Strongly agree } \\
3=\text { Neutral } \\
5=\text { Strongly disagree }\end{array}$ & 3.79 & 1.17 & $0.79 * * *$ \\
\hline 6. & $\begin{array}{l}\text { Transformation of the audit profession will best be progressed via MAFR, rather than } \\
\text { through existing and/or improved efforts within the audit firms themselves. }\end{array}$ & $\begin{array}{l}1=\text { Strongly agree } \\
3=\text { Neutral } \\
5=\text { Strongly disagree }\end{array}$ & 4.13 & 1.12 & $1.13 * * *$ \\
\hline 7. & $\begin{array}{l}\text { The lack of black registered auditors in South Africa is primarily indicative of the } \\
\text { disproportionately small pool of black Chartered Accountants and the disproportionate } \\
\text { racial demographic of qualifying chartered accountants. }\end{array}$ & $\begin{array}{l}1=\text { Strongly agree } \\
3=\text { Neutral } \\
5=\text { Strongly disagree }\end{array}$ & 2.77 & 1.28 & {$[0.23]$} \\
\hline
\end{tabular}

Note: An additional $t$-test was applied to statements $2-7$ in Tables 2 and 3 to determine whether the differences in findings between the two groups were significant. Only statements 5 and 6 showed significant differences at the 0.05 and 0.001 levels, respectively, meaning that the Big 4 audit firm partners show statistically stronger views than the non-Big 4 firm partners in respect of these two statements. Numbers shown in brackets represent negative numbers.

MAFR, mandatory audit firm rotation; SD, standard deviation.

$* *, * * *$ denote significance at $<$ or $=0.01$ and 0.001 levels, respectively (two-tailed).

comments raised by partners in this study that ' $[t]$ ransformation has been greatest in the Big 4 firms as compared to mid-tier and small firms'.

As explained by a senior EY South Africa director:

EY and many firms in the South African auditing profession understand the need for and have unreservedly fully embraced the need to transform. Accordingly, they have been transforming at all levels over the last three decades. Furthermore, EY and many other firms have contributed to the development of many black chartered accountants who are now in commerce and industry and making an outstanding contribution to our country's economy. (Bourne 2017:13)

The CEO of Deloitte Africa, in a letter to the IRBA, expressed sentiments similar to the other Big 4 firms:

Deloitte is firmly committed to accelerated transformation, not only within our own Firm, but also of the profession as a whole and we agree with the IRBA submission that MAFR is not the appropriate vehicle to achieve these objectives. We have a number of programmes and processes in place to continuously increase our transformation results. (Bam 2017:14)

\section{Reduced capacity to pursue transformation objectives}

There was strong sentiment that MAFR may impose additional costs on the audit firms, resulting in a negative financial impact on the ability of firms to invest in transformation and attract talent (Big 4 partner mean $=1.94$; non-Big 4 partner mean $=2.19 ; p<0.001$ ). From the results, the strongest convictions (means over 4 ) relate to disagreement with the idea that transformation of the audit profession will best be advanced via MAFR rather than through existing and/or improved efforts within the audit firms themselves. This is to be expected, as even the IRBA does not advocate MAFR as the best means to achieve transformation - it is likely that all parties agree that internal firm commitments and policies are the best means to improve black participation in the industry.

Based on the results of statements 3 and 4, the responding auditors feel that additional costs imposed on the firms from MAFR will inhibit the ability of firms to invest in transformation initiatives and will likely require a redirection 
of spending away from areas such as training and bursaries. The opinions of Big 4 firm leadership in their response letters to the IRBA consultation letter made it clear that they believed that the audit profession would become 'a poorer profession' as a result of MAFR, and this would necessarily hamper their ability to invest in transformation-related initiatives (Harber \& West 2017).

\section{Audit committee chairs' views on the rate of transformation of the auditing profession}

As per Table 4, the AC chairs neither significantly agreed nor disagreed with the idea that MAFR would reduce the ability of audit firms to pursue transformation objectives (statements 2-4). Perhaps this is because AC chairs did not feel in a position to make a judgement on the abilities of audit firms, financial or otherwise. However, as with the audit partners, they did not feel that MAFR would improve transformation of the profession (Statement 5 ; mean $=3.61 ; p<0.001$ ).

\section{The risk-reward trade-off facing black chartered accountants}

It has been suggested in the South African debate that the lack of transformation of audit partners is because of the disproportionately small pool of black chartered accountants and the disproportionate racial demographic of qualifying chartered accountants. This has been acknowledged by SAICA, which has responded with various transformation initiatives to promote the qualification of greater numbers of black chartered accountants (Nombembe 2017). The results from Statement 7 indicate that the Big 4 partners (mean $=2.47$; $p<0.01$ ) and the AC chairs (mean $=2.49 ; p<0.05$ ) tend to agree that the lack of numbers of chartered accountant graduates is partly to blame for the low numbers of black audit partners.

'The pool of black Chartered Accountants in the profession is too small to enable all firms to be able to attract this talent and due to this the big 4 traditionally attract them due to ability to pay competitive remuneration to what they can earn in commerce.'

'Firms do not have the ability to influence the efficacy of state education at primary, secondary and tertiary level. It is from those student ranks that the profession seeks recruits. If our maths education is poor, then how will we produce more CAs?'

Related to this, a common theme in the comments of the auditors was that black chartered accountants who qualify in the audit firms leave either immediately, or soon after, to pursue higher paying and/or lower risk opportunities in commerce and industry, outside of public practice. Here is a sample of representative comments from auditors:

'Being a registered auditor in a listed environment is a high risk position. There are so many other opportunities for African CA's with much less risk and higher reward, they are not interested in taking this high risk, high stress route for themselves.'

'The audit profession is a hard way of life and it takes years to get ready to have the acumen and skills to sign a listed set of accounts. Many, many potential black partners have been lured into commerce and industry for much more money than the firms can offer, at much reduced stress, and no regulatory (IRBA) review risk. Many examples of ex partners now as CFOs. MAFR impact on profitability of the firms will accelerate this trend. Bright, talented black Registered Auditors have significant career optionality, and a world of MAFR and regulatory review is a significant disincentive to a career as a partner signing listed accounts.'

'A Black CA(SA) will earn more in commerce with less risk.'

These sentiments were echoed by the AC chairs:

'The lack of black registered auditors is mainly due to the attractive financial packages available to black accountants from commerce, industry and the public sector which audit firms cannot compete with. Transformation and the training of black accountants has been very successful by the big firms.'

'Talented black CAs are reasonably plentiful, but they do not choose to work in audit firms as they have so many opportunities in the corporate world. Firms big and small find it very hard to retain these people. MAFR will not change this issue.'

There is clearly a problem in the audit profession that the IRBA needs to acknowledge and address. One audit partner explained that their firm invests considerable amounts of

TABLE 4: Audit committee chairs' perspectives on transformation.

\begin{tabular}{|c|c|c|c|c|c|}
\hline No. & Statement & Endpoints, midpoint & Mean & SD & Diff from neutral \\
\hline 2. & $\begin{array}{l}\text { MAFR will reduce the ability of audit firms to pursue internal transformation objectives, } \\
\text { that is, hinder the ability of firms to achieve transformation targets. }\end{array}$ & $\begin{array}{l}1=\text { Strongly agree } \\
3=\text { Neutral } \\
5=\text { Strongly disagree }\end{array}$ & 3.05 & 1.06 & 0.05 \\
\hline 3. & $\begin{array}{l}\text { MAFR will impose additional costs on the audit firms, resulting in a negative financial } \\
\text { impact on the ability of firms to invest in transformation and attract talent. }\end{array}$ & $\begin{array}{l}1=\text { Strongly agree } \\
3=\text { Neutral } \\
5=\text { Strongly disagree }\end{array}$ & 2.78 & 1.05 & [0.22] \\
\hline 4. & $\begin{array}{l}\text { The additional costs MAFR will impose on the audit firms will require a redirection of } \\
\text { spending away from areas such as training and bursaries and into tendering for work. }\end{array}$ & $\begin{array}{l}1=\text { Strongly agree } \\
3=\text { Neutral } \\
5=\text { Strongly disagree }\end{array}$ & 3.1 & 1.05 & 0.10 \\
\hline 5. & MAFR will improve the transformation statistics in the South African audit profession. & $\begin{array}{l}1=\text { Strongly agree } \\
3=\text { Neutral } \\
5=\text { Strongly disagree }\end{array}$ & 3.61 & 1.03 & $0.61 * * *$ \\
\hline 6. & $\begin{array}{l}\text { Transformation of the audit profession will best be progressed via MAFR, rather than } \\
\text { through existing and/or improved efforts within the audit firms themselves. }\end{array}$ & $\begin{array}{l}1=\text { Strongly agree } \\
3=\text { Neutral } \\
5=\text { Strongly disagree }\end{array}$ & 4.15 & 0.9 & $1.15 * * *$ \\
\hline 7. & $\begin{array}{l}\text { The lack of black registered auditors in South Africa is primarily indicative of the } \\
\text { disproportionately small pool of black Chartered Accountants and the disproportionate } \\
\text { racial demographic of qualifying chartered accountants. }\end{array}$ & $\begin{array}{l}1=\text { Strongly agree } \\
3=\text { Neutral } \\
5=\text { Strongly disagree }\end{array}$ & 2.49 & 1.21 & {$[0.51]^{*}$} \\
\hline
\end{tabular}

Note: $*, * *$ denote significance at $p<$ or $=0.05$ and 0.001 levels, respectively (two-tailed). Numbers shown in brackets represent negative numbers. MAFR, mandatory audit firm rotation; SD, standard deviation. 
time and resources in developing black chartered accountants, only to have 'large corporates ... head-hunting the black African talent in our firms'. The result, explained the partner, was that the audit firm is not recognised for the investment made but is rather criticised for poor transformation statistics. There was a considerable degree of unhappiness in this regard. Another partner explained that:

'.. in the broader context of [economic empowerment] one has the 'audit firms' competing with BIG-Business for a scarce resource. However, where a large listed company might only need, say 1 or 2 , African Black CA(SA)s in their business, audit firms HAVE to HAVE all of their audit partners as CA(SA)s and are therefore NOT able to match the salaries being offered by BIG-Business.'

\section{Black respondents' views on transformation of the auditing profession}

During the parliamentary hearings before the Standing Committee on Finance in February and March 2017, the chairman of the committee, Yunus Carrim, stated that transformation in the audit profession was too slow and it needed to speed it up. The rate at which black accountants and black-owned auditing firms were being empowered was considered by the committee to be too slow:

It cannot be that 23 years after our democracy, we still have a sector that is not transformed ... But also, the government must ensure that through the Mandatory Audit Firm Rotation's framework it has initiated, there is an increase in the use of black firms for auditing both in the public and private sectors. (Yunus Carrim, as quoted by Mputing 2017:1)

At these parliamentary hearings, the president of the Association for the Advancement of Black Accountants of Southern Africa (ABASA), Gugu Ncube, expressed support for MAFR and its ability to promote transformation. In addition, the interim chairman of the interest group, the Black Chartered Accountants Practitioners (BCAP), who is also the CEO of one of South Africa's largest black-owned audit firms, Victor Sekese, supported MAFR as a way for black-owned audit firms to get access to private sector audits, levelling the playing field and lessening the concentration of the market (Ensor 2017).

From this, it is clear that some organisations that represent black chartered accountants, such as ABASA and BCAP, are in support of MAFR improving transformation in South Africa. It is therefore important to separately analyse the survey responses of black respondents on this topic of transformation. Figure 4 represents the responses for Statement 5 from all the responding auditors who identified themselves as 'African black', 'Coloured' or 'Indian/Asian' (28 respondents). Figure 4 therefore excludes all respondents who identified themselves as 'white' or selected 'prefer not to answer' to the racial classification.

As is evident from Figure 4,75\% of the 28 respondents disagreed that MAFR would improve transformation in the audit profession (mean $=3.97$ ). These results are inconsistent with the opinions of the president of ABASA and the interim

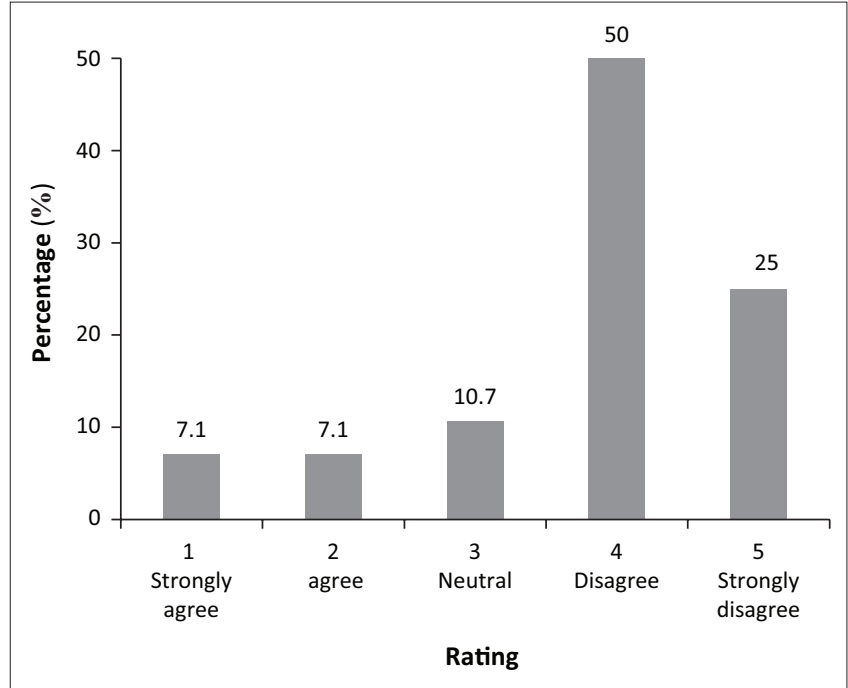

Note: Respondents $=28 ;$ mean $=3.97$.

FIGURE 4: Black audit partners' perspectives on transformation.

chair of BCAP, as mentioned. It would therefore not be appropriate to conclude that black auditors are necessarily in favour of MAFR as a means of improving black participation in the audit industry.

The results of the AC chairs show that only seven respondents who selected 'African black', 'Coloured' or 'Indian/Asian' provided responses: 2 - agree, 1 - neutral, 2 - disagree and 2 - strongly disagree. While the results favour disagreement, the small number of responses allows for limited inference and interpretation.

\section{Perspectives regarding mandatory audit firm rotation and market concentration}

Table 5 presents the findings with respect to statements on market concentration. The results for statements 15 and 16 show that Big 4 firm partners and AC chairs have significant reservations $(p<0.001)$ regarding the ability of mediumsized audit firms (non-Big 4) to appropriately perform the audits of the larger JSE listed companies and to provide competitive tender proposals, from a resources perspective. As may be expected, non-Big 4 partners disagree to some extent but do not express strong views to the contrary (means $=2.65$ and 2.56), indicating that a lack of resources may indeed be a concern.

It is important to note that the AC chairs express significant reservations in this regard. Considering that the $\mathrm{AC}$ is responsible for overseeing the tendering process, performing the due diligence work and making the recommendation of audit firms to the shareholders for approval, this result confirms the legitimacy of this argument against MAFR being effective to lower market concentration.

The CEO of SAICA has recognised this concern, stating what many respondents in the surveys expressed, namely that:

MAFR may detract from the real transformation initiatives that are so crucial within the South African context, as well as 
TABLE 5: Perspectives on market concentration considerations.

\begin{tabular}{|c|c|c|c|c|}
\hline No. & Statement & Big 4 Audit partners (mean) & Non-Big 4 Audit partners (mean) & Audit committee chairs (mean) \\
\hline 8 & $\begin{array}{l}\text { MAFR will allow other smaller audit firms, such as the mid-tier } \\
\text { firms, the opportunity to tender for these audit engagements. }\end{array}$ & 3.01 & $2.66^{*}$ & 2.68 \\
\hline 9 & $\begin{array}{l}\text { MAFR will reduce the concentration of 'big 4' audit firms providing } \\
\text { audit services for JSE listed companies. }\end{array}$ & $4.25 * * *$ & $3.58 * *$ & $3.37^{*}$ \\
\hline 10 & $\begin{array}{l}\text { The size of an audit firm's 'geographical footprint' (international } \\
\text { presence) is an important consideration for the audit committee } \\
\text { and shareholders in the appointment of a suitable audit firm. }\end{array}$ & $1.36 * * *$ & $1.78 * * *$ & $1.54 * * *$ \\
\hline 11 & $\begin{array}{l}\text { Non-'big } 4 \text { ' audit firms (mid-tier firms) have a sufficient } \\
\text { 'geographical footprint' (international presence) to be appointed as } \\
\text { auditors of large multinational companies on the JSE. }\end{array}$ & $4.10 * * *$ & $2.62 *$ & $3.71 * * *$ \\
\hline 12 & $\begin{array}{l}\text { In order to maintain audit efficiency, effectiveness and reduce the } \\
\text { overall cost, the audit committee seeks to appoint (or recommend } \\
\text { for appointment) the same audit firm in each of the geographic } \\
\text { areas and jurisdictions in which the group operates. }\end{array}$ & $1.60 * * *$ & $1.84 * * *$ & $1.59 * * *$ \\
\hline 13 & $\begin{array}{l}\text { Industry-specific knowledge and experience within the audit firm is } \\
\text { an important consideration for the audit committee and } \\
\text { shareholders in the appointment of a suitable audit firm. }\end{array}$ & $1.30 * * *$ & $1.80 * * *$ & $1.54 * * *$ \\
\hline 14 & $\begin{array}{l}\text { Non-'big 4' audit firms (mid-tier firms) have evident industry- } \\
\text { specific knowledge and experience to be appointed as auditors of } \\
\text { large multinational companies on the JSE. }\end{array}$ & $3.67 * * *$ & $2.68^{*}$ & $3.66 * * *$ \\
\hline 15 & $\begin{array}{l}\text { Medium-sized audit firms (non-'big } 4 \text { ') have the resources (money, } \\
\text { time, staff etc.) to appropriately perform the audits of the larger } \\
\text { JSE listed companies. }\end{array}$ & $3.90 * * *$ & $2.65^{*}$ & $3.67 * * *$ \\
\hline 16 & $\begin{array}{l}\text { Medium-sized audit firms (non-'big } 4 \text { ') have the resources (money, } \\
\text { time, staff etc.) to provide competitive tender proposals to secure } \\
\text { audit appointments. }\end{array}$ & $3.49 * * *$ & 2.56 & $3.56 * * *$ \\
\hline 17 & $\begin{array}{l}\text { Audit committees of JSE listed companies are likely to recommend } \\
\text { non-'big 4' audit firms for appointment as external auditors. }\end{array}$ & $3.85 * * *$ & $3.40^{*}$ & $3.56 * * *$ \\
\hline 18 & $\begin{array}{l}\text { Shareholders of JSE listed companies, in the AGM, are likely to } \\
\text { appoint non-'big 4' audit firms as external auditors. }\end{array}$ & $3.90 * * *$ & $3.52 * * *$ & $3.56 * * *$ \\
\hline 19 & $\begin{array}{l}\text { Considering that the performance of advisory services (non-audit } \\
\text { work) by an audit firm creates an independence threat that limits } \\
\text { or prevents that firm from being appointed as auditor, MAFR will } \\
\text { reduce the choice of audit firms available for appointment by the } \\
\text { audit committee. }\end{array}$ & $1.58 * * *$ & $2.14 * * *$ & $2.24 * * *$ \\
\hline 20 & $\begin{array}{l}\text { Non-'big } 4 \text { ' audit firms will be able to obtain more non-audit work if } \\
\text { larger firms restrict their advisory (non-audit) services in order to } \\
\text { make themselves available for appointment as auditors. }\end{array}$ & 3.04 & 2.76 & $2.59 * *$ \\
\hline
\end{tabular}

Note: An additional $t$-test was applied to statements 8-20 in Table 5 to determine whether the differences in findings between the two groups were significant. All statements show a statistically significant difference at the 0.05 level, with the exception of statements 8,12 and 20.

1 = Strongly agree; 3 = neutral (midpoint); 5 = strongly disagree

MAFR, mandatory audit firm rotation; AGM, annual general meeting; JSE, Johannesburg Stock Exchange.

$*, * *, * * *$ denote significance at $p<$ or $=0.05,0.01$ and 0.001 levels, respectively (two-tailed).

concerns that market concentration will not be addressed since rotation would tend to spiral upwards towards the bigger firms, rather than the other way around. (Nombembe 2017:7)

If the AC is reluctant to recommend for appointment, and/or the shareholders to formally appoint, non-Big 4 firms, then MAFR will not be successful in this regard. Counter intentionally, because the outgoing audit firm will not be eligible for reappointment, it may have the effect of even increasing concentration as there would be only three Big 4 firms left to consider. Some responding auditors argued further that, in some sectors, not all of the Big 4 firms are equally experienced, which may reduce the number of firms even further, to one or two.

The results from statements 17 and 18 are important. All three groups believe that, although non-Big 4 firms will have the opportunity to tender for appointment (Statement 8), it is unlikely that the AC will recommend them at the annual general meeting (AGM) for appointment. Even if they were to be recommended for appointment, it is unlikely that shareholders would be willing to appoint them. The non-Big 4 partners surprisingly also share these sentiments (means = 3.40, $p<0.05$; and 3.52, $p<0.001$, respectively). This could be because Big 4 auditors are associated with higher quality audit work, to the extent that researchers have used Big 4 auditors as a proxy for audit quality (Knechel et al. 2013). Therefore, ACs and shareholders would be reluctant to appoint non-Big 4 audit firms because of this perception.

The results for statements 10-14 provide further insight into why ACs may be reluctant to appoint non-Big 4 firms, especially with regard to the larger groups of companies listed on the JSE. The size of an audit firm's 'geographical footprint' is considered an important quality of the firm (Statement 10). Being present in a multinational group's various geographic areas of business is possibly seen as helping maintain audit efficiency, effectiveness and reducing the overall cost of the audit. The smaller firms are not seen to possess the required degree of international presence (Statement 11).

'Global reach is non-negotiable as global entities want to work with one person, never mind one firm. Non-Big 4 do not have advisory capability at any scale and will continue with their current scale which is very much based on individual skills of individuals in certain pockets i.e. tax or legal.'

Industry-specific knowledge and experience within the audit firm is another important consideration for the AC and shareholders in the appointment of a suitable audit firm 
(Statement 13) and again the AC chairs do not believe that the mid-tier firms have evident industry-specific knowledge and experience to be appointed as auditors of large multinational companies on the JSE. Non-Big 4 firm partners believe that they do have the required knowledge and experience; Big 4 firms disagree. Comments raised expressed specific concern regarding the larger and more niche-industry companies, such as banks, mining, insurance and telecommunications.

From these findings it may be concluded that, whereas the ACs of the smaller companies may consider the non-Big 4 firms for appointment, it is unlikely that the larger company committees will do so. The results also indicate that many mid-tier firms will be unlikely to tender for the larger companies but may do so for the medium to smaller companies. It should be acknowledged that these findings are biased in favour of the larger companies, considering that the top 100 JSE listed company AC chairs were surveyed and not the approximately 250 other companies listed on the JSE main board and AltX board. There may still be considerable opportunity for mid-tier firms to stand a realistic opportunity of appointment over these smaller companies.

\section{Considering non-audit services}

With regard to Statement 19, auditors and AC chairs strongly agree that MAFR will have the effect of reducing the choice of audit firms available for appointment by the AC. These results imply that audit firms will not likely resign from nonassurance services so as to be eligible for appointment as auditor from 2023. The comments from audit partners provide a possible reason for these findings:

'There is also the possibility that the Big 4 will pick their battles and rather take on advisory / non-audit work which does not require the same level of independence scrutiny that audit requires.'

‘Big 4 firms will not accept audit only assignments. The mark up on non-audit assignment are huge in comparison to audits. Remuneration from audits only is so low that no accountant will want to carry the audit risk in comparison to income received from audits only.'

There is therefore the possibility that audit firms will not tender for appointment as auditors to companies to which they either currently provide services or from which they intend to secure advisory services. The results from Statement 20 do not show strong agreement with the idea that non-Big 4 firms will be able to obtain more non-audit work if larger firms restrict their advisory (non-audit) services in order to make themselves available for appointment as auditors. This could be because Big 4 firms may not be willing to resign from advisory services or it could be because ACs may be reluctant to appoint non-Big 4 firms for advisory work. According to one AC chair:

'... [u]nfortunately, the non-Big 4 firms have not demonstrated that they have built up specialist advisory skills to service large multinational companies.'

Advisory services are perceived as less risky and more lucrative than assurance, and as such, may mean that Big 4 firms will prioritise them over audit. This trend may cause the industry to become more highly concentrated if ACs remain unwilling to appoint non-Big 4 firms as auditors.

'MAFR will limit competition as instead of having 4 of the big 4 bidding, it will be limited to 3 and if another does the internal work then there will only be 2 firms in the tender process.'

On the other hand, if ACs are willing to consider non-Big 4 firms for appointment as audit, then this seeming preference of Big 4 firms for advisory work could result in an opportunity for mid-tier firms to secure appointments as auditors. Nonetheless, it stands to reason that from a long-term perspective, a prioritisation of advisory work over audit, resulting from the perception of higher risk and lower profitability in audit, can only be detrimental to the future of the profession and audit quality. The IRBA needs to address these concerns and the possible threat this poses to audit quality. Many respondents identified a need for the IRBA to consider the implications of current Companies Act restrictions on advisory services and the impact that these will have after implementation of MAFR:

'The current 5-year restrictions created by Section 90 reduces choice by companies to use the best service provider on nonaudit services. S90(2) of the Companies Act has a significant impact on audit committee's available choices, especially in light of the 5-year cooling off period.'

Based on these comments, perhaps if Section 90 of the Companies Act did not prescribe a 5 prior-year restriction on certain advisory services, then ACs would receive more tenders for audit appointments after implementation of MAFR in 2023. As it stands, for a firm (either large or midtier) to tender for auditor of a company after 2023, it would need to remove itself from all advisory services for the next 5 to 6 years in order to be eligible for appointment. In light of Section 90, a scenario whereby audit firms prioritise advisory services over audit services is likely to limit the attraction of audit firms to compete for the audit, counter to the IRBA's intentions.

\section{Conclusions and suggestions for future research}

The study explored perceptions of auditors and AC chairs regarding the IRBA's intention to expedite transformation and reduce concentration in the audit industry through MAFR. The study found that it is unlikely that MAFR will improve transformation in the audit industry. Results indicate that it may even undermine the capacity of audit firms to achieve their internal transformation targets, thereby slowing the rate of transformation in the industry as a whole. Both the Big 4 and the non-Big 4 firms believe that MAFR will impose significant additional costs on the industry and will require a redirection of spending away from areas such as training and bursaries into tendering for work. It is concluded that the best means of transforming the industry is to allow, encourage and support the firms to continue pursuing their own internal initiatives. 
With respect to concentration, the results indicate that MAFR may even contribute to increasing the degree of concentration of the Big 4 firms auditing JSE listed companies. All responding groups, including non-Big 4 firms, believe it is unlikely that either ACs or shareholders will recommend mid-tier firms for appointment at AGMs. The primary reasons for this appear to be a concern around the lack of resources, skills, experience and international presence of the mid-tier firms in comparison to the Big 4 firms. If the outgoing Big 4 firm is not eligible for reappointment on rotation under MAFR, then it seems likely that ACs and shareholders will reduce their considerations down to three firms. This further concentrates the market. These findings offer evidence consistent with the arguments provided by the leadership of the Big 4 audit firms in 2017, in response to the IRBA consultation paper (Bam 2017; Bourne 2017; Harber \& West 2017; Oddy 2017; Shango 2017).

The concerns raised by the auditors and AC chairs reiterated the opinion that audit firms are struggling to transform because talented black chartered accountants who qualify through them in public practice choose to leave for higher paying and less risky corporate opportunities. In the words of one auditor, 'the risk-reward trade-off' is skewed in favour of commerce and industry. This lack of appeal of the audit profession is hindering its efforts to transform. In the longer term, if the profession cannot retain talent (black professionals or otherwise), this will present a considerable threat to audit quality.

The results contain important considerations for those in the profession and the IRBA on allowing the profession to improve the rate of black participation in a sustainable and responsible manner. The results of this study are consistent with the views of the Big 4 audit firms, as per their official response letters to the IRBA consultation paper (Harber \& West 2017). However, the study contributed a more representative perspective, including the views of a wider group of stakeholders, notably AC chairs and non-Big 4 auditors. The considerable degree of consensus among respondents confirms the criticisms of MAFR as an appropriate tool to improve transformation or reduce market concentration, identifying the potential for counterintentional consequences. The results highlight the urgent need for the IRBA to consider how to make the profession more attractive as a career of choice for professional accountants, without sacrificing audit quality. It is important to note that this study does not offer any conclusion with regard to the perceived necessity or efficacy of MAFR in terms of its primary objective, that being the improvement of auditor independence and audit quality.

This study has implications for future research on transformation and concentration in the audit industry as well as the possible direct and indirect consequences of MAFR in South Africa. In a paper on auditing research, Hay (2015) explains that the issues at the frontier of auditing research include two kinds of research questions, namely those that emerge from current practical problems or issues and those that stem from previous research. Hay (2015) states that a high proportion of research areas in auditing are linked to professional concerns and that these need to remain a priority. It is submitted that the issue of whether to pursue MAFR in South Africa, as well as the priority of transformation in the profession, are prime examples of such issues. Future research could address a broader set of issues around MAFR and target a wider range of stakeholder groups such as shareholders or company executives. Researchers could take the conclusions of this study and explore them further to suggest alternative means of aiding the profession to speed up transformation and make the profession more appealing to professional accountants in order to retain talent. Care should be taken when drawing inferences from these results, as this study reports only perceptions of stakeholders, albeit those experienced with the audit profession.

\section{Acknowledgements}

The views expressed in this article are those of the authors or the respondents, as clearly indicated, and not an official position of the University of Cape Town or University of Johannesburg.

\section{Competing interests}

The authors declare that they have no financial or personal relationships that may have inappropriately influenced them in writing this article.

\section{Authors' contributions}

All authors equally contributed to the research and writing of this article. M.H. and B.M. conceptualised the study with data collected and analysed in collaboration. Initial drafts of the manuscript were written by M.H., with B.M. providing the review and comments for improvement and amendment throughout. Both authors read and approved the final version of the manuscript.

\section{References}

Agnew, H., 2016, 'Audit merry-go-round increases competition but limits choice', Financial Times Online, viewed 07 May 2016, from https://www.ft.com/content/ a5ba734a-b577-11e5-8358-9a82b43f6b2f.

Aschauer, E. \& Quick, R., 2018, 'Mandatory audit firm rotation and prohibition of auditor-provided tax services - Evidence from investment consultants' perceptions', International Journal of Auditing 1, 1-19.

Ball, F., Tyler, J. \& Wells, P., 2015, 'Is audit quality impacted by auditor relationships?', Journal of Contemporary Accounting \& Economics 11(2), 166-181. https://doi. org/10.1016/j.jcae.2015.05.002

Bam, L., 2017, Chief executive officer of Deloitte Inc. South Africa-Response to the IRBA consultation paper on MAFR (Received directly from Deloitte Inc.).

Bamber, E.M. \& Iyer, V.M., 2007, 'Auditors' identification with their clients and its effect on auditors' objectivity', Auditing: A Journal of Practice \& Theory 26(2), 1-24. https://doi.org/10.2308/aud.2007.26.2.1

Beasley, M.S., Carcello, J.V., Hermanson, D.R. \& Neal, T.L., 2009, 'The audit committee oversight process', Contemporary Accounting Research 26(1), 65-122. https://doi. org/10.1506/car.26.1.3

BEE Commission, 2001, Black economic empowerment commission report viewed 05 June 2017, from https://www.westerncape.gov.za/text/2004/5/ beecomreport.pdf

Bergner, J.M., 2011, 'Auditor rotation and auditor independence: An investigation using social identity theory and accountability', Thesis, Graduate School, University of Kentucky, KY. 
Bourne, M., 2017, Professional Practice Director of EY Inc. South Africa-Response to the IRBA Consultation Paper on MAFR (Received directly from EY Inc.)

Brazel, J.F., Carpenter, T.D. \& Jenkins, J.G., 2010, 'Auditors' use of brainstorming in the consideration of fraud: Reports from the field', The Accounting Review 85(4), 1273-1301. https://doi.org/10.2308/accr.2010.85.4.1273

Cameran, M., Francis, J.R., Marra, A. \& Pettinicchio, A., 2015, 'Are there adverse consequences of mandatory auditor rotation? Evidence from the Italian experience', Auditing: A Journal of Practice \& Theory 34(1), 1-24. https://doi. org/10.2308/ajpt-50663

Casterella, J.R. \& Johnston, D., 2013, 'Can the academic literature contribute to the debate over mandatory audit firm rotation?', Research in Accounting Regulation 25(1), 108-116. https://doi.org/10.1016/j.racreg.2012.11.004

Chen, K. \& Zhou, J., 2007, 'Audit Committee, board characteristics, and audito switch decisions by Andersen's clients', Contemporary Accounting Research 24(4), 1085-1117. https://doi.org/10.1506/car.24.4.2

Chu, L., Simunic, D.A., Ye, M. \& Zhang, P., 2018, 'Transaction costs and competition among audit firms in local markets', Journal of Accounting and Economics 65(1), 129-147. https://doi.org/10.1016/j.jacceco.2017.11.004

Cohen, J., Krishnamoorthy, G. \& Wright, A., 2010, 'Corporate governance in the PostSarbanes-Oxley Era: Auditors' experiences', Contemporary Accounting Research 27(3), 751-786. https://doi.org/10.1111/j.1911-3846.2010.01026.x

Daugherty, B.E., Dickins, D., Hatfield, R.C. \& Higgs, J.L., 2012, 'An examination of partner perceptions of partner rotation: Direct and indirect consequences to audit quality', Auditing: A Journal of Practice \& Theory 31(1), 97-114. https://doi. org/10.2308/ajpt-10193

DeAngelo, L.E., 1981, 'Auditor size and audit quality', Journal of Accounting and Economics 3, 183-199. https://doi.org/10.1016/0165-4101(81)90002-1

Ensor, L., 2017, Push to transform auditing sector, Association for the Advancement of Black Accountants of Southern Africa (ABASA), viewed 17 February 2018, from https://www.abasa.org.za/push-to-transform-auditing-sector/

European Commission, 2014, Directorate-general for financial stability, EU audit reform. Directive 2014/56/EU and Regulation 537/2014, viewed 02 May 2016 from https://ec.europa.eu/info/business-economy-euro/company-reportingfrom https://ec.europa.eu/info/business-economy-euro/company-reportingand-auditi

Ewelt-Knauer, C., Gold, A. \& Pott, C., 2013, 'Mandatory audit firm rotation: A review of stakeholder perspectives and prior research', Accounting in Europe 10(1) 27-41.

Fontaine, R., Khemakhem, H. \& Herda, D.N., 2016, 'Audit committee perspectives on mandatory audit firm rotation: Evidence from Canada', Journal of Management and Governance 20(3), 485-502. https://doi.org/10.1007/s10997-015-9308-2

Francis, J.R., Michas, P.N. \& Seavey, S.E., 2013, 'Does audit market concentration harm the quality of audited earnings? Evidence from audit markets in 42 countries' Contemporary Accounting Research 30(1), 325-355. https://doi.org/10.1111/ j.1911-3846.2012.01156.x

Gerokos, J. \& Syverson, C., 2015, 'Competition in the audit market: Policy implications' Journal of Accounting Research 53(4), 725-775. https://doi.org/10.1111/1475$679 X .12087$

Ghafran, C. \& O'Sullivan, N., 2013, 'The governance role of audit committees: Reviewing a decade of evidence', International Journal of Management Reviews $15,381-407$.

Grant Thornton South Africa, 2018, SizweNtsalubaGobodo joins Grant Thornton network, viewed 18 November 2018, from https://www.grantthornton.co.za/ Newsroom/sizwentsalubagobodo-joins-network/.

Hakwoon, K., Hyoik, L. \& Jong Eun, L., 2015, 'Mandatory audit firm rotation and audit quality', The Journal of Applied Business Research 31(3), 1089-1106. https://doi. org/10.19030/jabr.v31i3.9245

Harber, M., 2016, 'An analysis of audit partner perceptions regarding the state of auditor independence in South African audit firms', in Proceedings of Southern African Accounting Association Conference held in Cape Town, Sepetmber 2016 Cape Town, September 02, 2016, pp. 6-24.

Harber, M. \& West, S., 2017, 'An analysis of the IRBA consultation paper on mandatory audit firm rotation together with key organisation responses', in Proceedings of the Southern African Accounting Association: Biennial International Conference held in Drakensburg, KZN, Champagne Sports Resort, Drakensberg, June 28-30, 2017, pp. 141-170.

Hay, D., 2015, 'The frontiers of auditing research', Meditari Accountancy Research 23(2), 158-174. https://doi.org/10.1108/MEDAR-12-2014-0062

Independent Regulatory Board for Auditors, IRBA, 2015, Consultation paper: Measures to strengthen auditor independence, viewed 09 November 2015, from $\mathrm{http}: / /$ www.irba.co.za/news-headlines/press-releases.

Independent Regulatory Board for Auditors (IRBA), 2016a, The IRBA announces measures to strengthen auditor independence and enhance investor protection viewed 29 August 2016, from http://www.irba.co.za/news-headlines/pressreleases/the-irba-announces-measures-to-strengthen-auditor-independenceand-enhance-investor-protection
Independent Regulatory Board for Auditors (IRBA), 2016b, The IRBA consultation paper, The Independent Regulatory Board for Auditors, viewed 15 November 2016, from https://www.irba.co.za/news-headlines/press-releases

Independent Regulatory Board for Auditors (IRBA), 2017a, Gazetted rule of mandatory audit firm rotation - Gazette No. 40888, viewed 09 June 2017, from https://www. irba.co.za/news-headlines/general-news/rule-on-mandatory-audit-firm-rotation.

Independent Regulatory Board for Auditors (IRBA), 2017b, IRBA Newsletter 37, viewed 02 May 2017, from https://www.irba.co.za/library/irba-news

Jackson, A.B., Moldrich, M. \& Roebuck, P., 2008, 'Mandatory audit firm rotation and audit quality', Managerial Auditing Journal 23(5), 420-437. https://doi. org/10.1108/02686900810875271

Knechel, W., Krishnan, G.V., Pevzner, M., Shefchik, L.B. \& Velury, U.K., 2013, 'Audit quality: Insights from the academic literature', Auditing: A Journal of Practice \& Theory 32, 385-421. https://doi.org/10.2308/ajpt-50350

Kwon, S.Y., Lim, Y. \& Simnett, R., 2014, 'The effect of mandatory audit firm rotation on audit quality and audit fees: Empirical evidence from the Korean audit market', Auditing: A Journal of Practice \& Theory 33(4), 167-196. https://doi.org/10.2308/ Auditing: $A$ Jou

ennox, C.S., Wu, X. \& Zhang, T., 2014, 'Does mandatory rotation of audit partners improve audit quality?', The Accounting Review 89(5), 1775-1803. https://doi. improve audit quality?',

Lu, T. \& Sivaramakrishnan, K., 2009, 'Mandatory audit firm rotation: Fresh look versus poor knowledge', Journal of Accounting and Public Policy 28, 71-91. https://doi. org/10.1016/j.jaccpubpol.2009.01.006

Marais, H., 2010, South Africa pushed to the limit. The political economy of change, 1st edn., UCT Press, Cape Town.

Marx, B., 2009, 'An analysis of audit committee responsibilities and disclosure practices at large listed companies in South Africa', South African Journal of Accounting Research 23(1), 31-44. https://doi.org/10.1080/10291954.2009.11435138

Mputing, A. (2017, June 21), 'Domination of the auditing landscape by four major auditing firms comes under scrutiny', SA Parliament News, South African Parliament, viewed 18 May 2018, from https://www.parliament.gov.za/news/ domination-auditing-landscape-four-major-auditing-firms-comes-under-scrutiny

Niselow, T., 2018, 'Nkonki Inc to close doors in wake of public sector work ban', Fin24. com, viewed 18 November 2018, from https://www.fin24.com/Companies/ Financial-Services/nkonki-inc-to-close-doors-in-wake-of-public-sector-workban-20180424

Nombembe, T., 2017, Mandatory audit firm rotation: SAICA submission to parliament's Standing Committee on Finance (SoCF), viewed 15 June 2017, from https://www. saica.co.za/Technical/Assurance/Latestdevelopmentsintheauditingprofession/ MandatoryAuditFirmRotation/tabid/4047/language/en-US/Default.aspx

Oddy, M., 2017, Chief executive officer of KPMG Inc. South Africa-Response to the IRBA consultation Paper on MAFR (Received directly from KPMG Inc.).

Peyper, L. (2017, March 17), 'New audit regulation won't improve independence - auditors', Fin24 Online, viewed 20 March 2017, from http://www.fin24. com/Companies/Financial-Services/new-audit-regulation-wont-improveindependence-auditors-20170317

Ponte, S., Roberts, S. \& Van Sittert, L., 2007, 'Black economic empowerment, business and the state in South Africa', Development and Change 38(5), 933-955. https:// doi.org/10.1111/j.1467-7660.2007.00440.

Ramon, K., 2016, The CFO forum response to IRBA's consultation paper issued on 25 October 2016, viewed 25 February 2017, from https://cfo.co.za/article/cfosreject-mandatory-audit-rotation-christine-ramon

RSA, 2008, The Companies Act, 2008 (No 71 of 2008), c.94, viewed 26 May 2018, from https://www.gov.za/documents/companies-act

Shango, D., 2017, Chief executive officer of PwC Inc. South Africa-Response to the IRBA consultation paper on MAFR (Received directly from PwC Inc.)

South African Institute of Chartered Accountants (SAICA), 2017, The South African Institute of Chartered Accountants (SAICA) annual integrated report 2017, viewed 18 November 2018, from https://www.saica.co.za/About/SAICAAnnualReport/ tabid/1219/language/en-US/Default.aspx

Stefaniak, C.M., Robertson, J.C. \& Houston, R.W., 2009, 'The causes and consequences of auditor switching: A review of the literature', Journal of Accounting Literature $28,47-121$

Tepalagul, N. \& Lin, L., 2015, 'Auditor independence and audit quality: A literature review', Journal of Accounting, Auditing \& Finance 30(1), 101-121. https://doi. org $/ 10.1177 / 0148558 \times 14544505$

Trivellas, P., Akrivouli, Z., Tsifora, E. \& Tsoutsa, P., 2015, 'The impact of knowledge sharing culture on job satisfaction in accounting firms: The mediating effect of general competencies', Procedia Economics and Finance 19(15), 238-247. https:// doi.org/10.1016/S2212-5671(15)00025-8

Velte, P. \& Stiglbauer, M., 2012, 'Audit market concentration in Europe and its influence on audit quality', International Business Research 5(11), 146-161. https://doi.org/10.5539/ibr.v5n11p146

World Economic Forum, WEF, 2017, The global competitiveness report 2017-2018, viewed 25 February 2018, from www.weforum.org/gcr. 